\title{
Posição do Paciente Anestesiado e Perfusão Cerebral: Catástrofes Previsíveis
}

Cullen e Kirby relataram recentemente ${ }^{1}$ o caso de uma paciente submetida à artroscopia do ombro sob anestesia geral, que sofreu uma complicação catastrófica e terminou em estado vegetativo permanente. Tinha 47 anos, sem problemas de saúde, com pressão arterial pré-operatória $125 \times 83$ $\mathrm{mmHg}$. Recebeu como medicação pré-anestésica meperidina $50 \mathrm{mg}$, hidroxizina $40 \mathrm{mg}$ e glicopirrolato $0,2 \mathrm{mg}$ por via intramuscular. A indução da anestesia foi feita com propofol $200 \mathrm{mg}$, succinilcolina $100 \mathrm{mg}$ e lidocaína $30 \mathrm{mg}$ por via venosa, seguida de intubação traqueal. Como apresentasse um episódio hipertensivo, recebeu $50 \mathrm{mg}$ de labetalol por via venosa. A anestesia foi mantida com isoflurano $2,0 \%$, óxido nitroso $60,0 \%$ e oxigênio. A paciente foi colocada na posição de "cadeira de praia" para a realização do procedimento. Vinte minutos após o início, a pressão arterial diminuiu para $100 \times 60 \mathrm{mmHg}$ e em seguida para 80 a $90 \mathrm{mmHg}$ (sistólica), assim permanecendo até o final da intervenção cirúrgica. $\mathrm{A} \mathrm{SatO}_{2}$ manteve-se em $100 \%$ e a $\mathrm{P}_{\mathrm{ET}} \mathrm{CO}_{2}$ em aproximadamente $30 \mathrm{~mm} \mathrm{Hg}$ durante todo o procedimento.

Chegou à sala de recuperação pós-anestésica (SRPA) com pressão arterial $113 \times 60 \mathrm{mmHg}$ mas inconsciente, permanecendo intubada. Foi administrada naloxona $0,1 \mathrm{mg}$ por via venosa mas ela não respondeu e não movimentou as extremidades. Outra dose de naloxona $0,1 \mathrm{mg}$ foi injetada 35 minutos após a admissão à SRPA, sem resposta. A seguir foram sucessivamente administradas mais três doses de naloxona e duas de fisostigmina, sem resultado. A intubação traqueal foi mantida, com oxigenação perfeita. A paciente permaneceu sem resposta a comando verbal e estímulo doloroso, com reflexos diminuídos bilateralmente. A avaliação neurológica sugeriu uma síndrome diencefálica, possivelmente infarto cerebral.

A tomografia axial computadorizada do crânio, a princípio, foi normal, mas no quinto dia pós-operatório acusou edema cerebral e oclusão da cisterna. A ressonância magnética realizada uma semana depois mostrou alterações em ambos os hemisférios cerebrais sugestivas de infartos corticais, abrangendo os lobos anterior e temporal, sem edema ou hérnia significativos. Em nenhuma ocasião houve evidência de sangramento intracraniano. Após duas semanas, apresentava escore 3 na escala de coma de Glasgow. Tinha reflexos corneanos, hiper-reflexia, hipertonia muscular e ausência de resposta a estímulo doloroso nas quatro extremidades. O diagnóstico foi de estado vegetativo permanente. Esse caso dramático ilustra a importância do posicionamento do paciente anestesiado para procedimento cirúrgico. A "cadeira de praia" permite que o paciente permaneça sentado em ângulos que variam de $30^{\circ}$ a $90^{\circ}$ acima do plano horizontal e é ideal para procedimentos artroscópicos no ombro, evitando alterações da anatomia intra-articular e facilitando o acesso do cirurgião, ao contrário do que ocorre com a posição de decúbito lateral.

Não obstante, alterações importantes acontecem quando o paciente assume a posição sentada, notadamente redução de pressão arterial média (PAM), pressão venosa central, volume sistólico, débito cardíaco e $\mathrm{PaO}_{2}{ }^{2}$. No indivíduo nãoanestesiado, essas alterações são compensadas por aumento da resistência vascular sistêmica que pode ser da ordem de $30 \%$ a $60 \%{ }^{3}$. Contudo, essa resposta é bloqueada pelo efeito vasodilatador dos anestésicos que, além disso, podem diminuir também o débito cardíaco. A pressão de perfusão cerebral (PPC) reduz-se em cerca de $15 \%$ na posição sentada no paciente não-anestesiado ${ }^{2}$, podendo diminuir mais ainda durante a anestesia por causa da vasodilatação e da redução do retorno venoso.

São clássicas as observações de Enderby ${ }^{4}$ de que a pressão arterial sistólica (PAS) sofre um decréscimo de 0,8 $\mathrm{mmHg}$ por $1,0 \mathrm{~cm}$ de elevação da região considerada no plano vertical em relação ao nível do coração. Como a PAM é diretamente proporcional à PAS, é óbvio que a simples elevação da cabeça em relação ao nível do coração acarreta diminuição da PAM no território intracraniano, mais acentuada durante anestesia pelos motivos já apontados.

Por sua vez, a PPC depende diretamente da PAM, segundo a equação:

$$
\mathrm{PPC}=\mathrm{PAM}-\mathrm{PVCe}^{*}
$$

É clássico também o conceito de que o mecanismo de autoregulação do fluxo sangüíneo cerebral (FSC) tende a manter constante esse fluxo entre os valores de PAM de 50 a 150 $\mathrm{mmHg}{ }^{5}$. Quando a PAM diminui abaixo de $50 \mathrm{mmHg}$, o mecanismo de auto-regulação deixa de funcionar e o FSC diminui linear e perigosamente com a PPC.

Em função dessas considerações, a manutenção da PAM em valores não-inferiores a $50 \mathrm{mmHg}$ tem sido reconhecida como limite de segurança em anestesia hipotensiva com finalidade de redução do sangramento perioperatório ${ }^{6}$.

Nesse ponto, duas considerações importantes devem ser feitas.

Em primeiro lugar, na posição sentada a PAM ao nível do encéfalo é menor do que aquela medida no membro superior na posição supina, exatamente em função da observações de Enderby já mencionadas ${ }^{4}$. Muitas vezes, essa diferença é ignorada pelo anestesiologista, o que pode colocar em risco a perfusão cerebral adequada durante o procedimento na posição sentada.

Em segundo lugar, o limite inferior da PAM $=50 \mathrm{mmHg}$ para o mecanismo de auto-regulação do FSC tem sido questio-

${ }^{\star} \mathrm{PVCe}=$ Pressão Venosa Central, valor normal $\cong 8 \mathrm{~mm} \mathrm{Hg}$ 
nado por alguns autores ${ }^{7,8}$, que preferem trabalhar com 0 valor médio de $80 \mathrm{mmHg}$, abaixo do qual o mecanismo deixaria de funcionar de forma adequada e o FSC diminuiria, sobretudo nos casos de pacientes hipertensos mal controlados.

No caso em questão, a pressão arterial foi monitorada por método não-invasivo no braço e tudo indica que o gradiente de pressão entre braço e encéfalo foi ignorado. Considere-se a paciente na "cadeira de praia", com um desnível no plano vertical da ordem de $30 \mathrm{~cm}$ entre a base do encéfalo (mais elevada) e o coração. Pressão arterial da ordem de $80 \times 45 \mathrm{mmHg}$ monitorada no braço corresponde à PAM de $56 \mathrm{mmHg}$. Entretanto, a diferença da PAS entre coração e base do encéfalo em virtude da posição mais elevada desta, é a da ordem de $24 \mathrm{mmHg}$, o que traz a PAS na base do encéfalo para $56 \mathrm{mmHg}$ e a PAM para $48 \mathrm{mmHg}$, isto sem considerar provável alteração também da PAD. Na porção cefálica do córtex cerebral, mais elevada do que a base do encéfalo, deve-se adicionar uma distância aproximada de mais $10 \mathrm{~cm}$ em relação ao nível do coração, o que traria a PAS para $48 \mathrm{mmHg}$ e a PAM para $43 \mathrm{mmHg}$, na mesma situação.

A análise desses números é coerente com o quadro final da paciente em questão. A tomografia axial computadorizada no quinto dia pós-operatório mostrou edema cerebral e oclusão da cisterna; a ressonância magnética indicou infartos corticais em ambos os hemisférios, mas sem nenhuma evidência de sangramento intracraniano. As lesões foram, portanto, compatíveis com hipoperfusão cerebral ocorrida no intraoperatório. Ressalte-se o fato de que a paciente foi anestesiada com isoflurano, um anestésico com conhecidas propriedades vasodilatadoras, o que certamente dificultou um possível aumento da resistência vascular sistêmica, compensatório da diminuição da PAM e dos outros parâmetros circulatórios já citados, provocada pela posição sentada.

As lições de um quadro catastrófico, como o descrito, devem ser transpostas para outras situações em que a intervenção cirúrgica é realizada em céfalo-aclive e o cirurgião solicita técnica anestésica hipotensiva para reduzir o sangramento operatório.

Uma delas é a realização de plástica de mama na posição sentada, com anestesia peridural e sedação. Nesse caso, a diminuição da PAM no encéfalo imposta pelo céfalo-aclive dificilmente será compensada pelo aumento da resistência vascular sistêmica, uma vez que o bloqueio peridural (assim como o isoflurano no quadro descrito) tende a provocar vasodilatação e redução dessa resistência. Sob sedação, é difícil para o anestesiologista surpreender sinais de hipoperfusão cerebral durante o procedimento e a catástrofe pode tornar-se patente apenas no pós-operatório.

O conhecimento das alterações fisiológicas relacionadas com a posição sentada bem como dos efeitos da gravidade sobre a pressão arterial (e portanto a perfusão) no encéfalo, é fundamental para a prevenção de complicações neurológicas graves em procedimentos cirúrgicos realiza- dos nessa posição, qualquer que seja a técnica anestésica empregada.

Unitermos: ANESTESIA, Geral; COMPLICAÇÕES: lesão neurológica; posicionamento.

José Roberto Nociti, TSA

Membro do Conselho Editorial da Revista Brasileira

de Anestesiologia; Vice-Presidente da World

Federation of Societies of Anaesthesiologists;

Responsável pelo CET-SBA Santa Casa de

Misericórdia de Ribeirão Preto, SP

\section{Positioning of the Anesthetized Patient and Cerebral Perfusion: Foreseeable Catastrophes}

Recently, Cullen and Kirby ${ }^{1}$ reported the case of a patient undergoing arthroscopy of the shoulder under general anesthesia, who developed a catastrophic complication leading to a permanent vegetative state. The patient was 47 years old, healthy, with preoperative blood pressure of $125 \times 83 \mathrm{mmHg}$. Pre-anesthetic medication consisted of the intramuscular administration of $50 \mathrm{mg}$ of meperidine, $40 \mathrm{mg}$ of hydroxyzine and $0.2 \mathrm{mg}$ of glycopyrrolate. Anesthetic induction was achieved with the intravenous administration of $200 \mathrm{mg}$ of propofol, $100 \mathrm{mg}$ of succinylcholine and $30 \mathrm{mg}$ of lidocaine followed by endotracheal intubation. As the patient developed hypertension, $50 \mathrm{mg}$ of labetalol were administered intravenously. Anesthesia was maintained with $2.0 \%$ isoflurane, $60.0 \%$ nitrous oxide and oxygen. The patient was placed in the beach chair position for the procedure. Twenty minutes after the beginning of the surgery the blood pressure decreased to $100 \times 60 \mathrm{mmHg}$ and then to 80 to $90 \mathrm{mmHg}$ (systolic) remaining at this level until the end of the procedure. SatO remained at $100 \%$ and $\mathrm{P}_{\mathrm{ET}} \mathrm{CO}_{2}$ approximately $30 \mathrm{mmHg}$ during the procedure.

When the patient arrived at the recovery room, she was unconscious but her blood pressure was $113 \times 60 \mathrm{mmHg}$ and she remained intubated. Intravenous naloxone, $0.1 \mathrm{mg}$, was administered without response or movement of the extremities. Another dose of $0.1 \mathrm{mg}$ of naloxone was administered 35 minutes after arrival to the recovery room, but the patient did not respond. Three more doses of naloxone and two of physostigmine were administered unsuccessfully. Tracheal intubation was maintained with good oxygenation. The patient was unresponsive to verbal commands and to painful stimuli and deep tendon reflexes were diminished bilaterally. Neurological evaluation suggested a diencephalic syndrome, probably cerebral infarction.

At first, axial CT of the head was normal, but on the $5^{\text {th }}$ postoperative day it showed cerebral edema and occlusion of the cistern. One week after the procedure, the MRI showed 
changes in both brain hemispheres suggestive of cortical infarctions in the anterior and temporal lobes without edema or herniation. There was no indication of intracranial bleeding. After two weeks she presented a score of 3 on the Glasgow scale. She presented corneal reflexes, hyperreflexia, increased muscle tone and no response to painful stimuli in all four extremities. A diagnosis of permanent vegetative state was made.

This dramatic case illustrates the importance of patient positioning for surgical procedures. The beach chair position allows the patient to remain in the sitting position in angle that vary from $30^{\circ}$ to $90^{\circ}$ above the horizontal plane, which is ideal for arthroscopic surgeries of the shoulder avoiding changes in the intra-articular anatomy and making the access easier for the surgeon, which does not happen with the lateral decubitus.

Nonetheless, important changes occur when the patient is in the sitting position, notably a reduction in the mean arterial pressure (MAP), central venous pressure, systolic volume, cardiac output and $\mathrm{PaO}_{2}{ }^{2}$. In the non-anesthetized individual, those changes are compensated by an increase in systemic vascular resistance, which can vary from $30 \%$ to $60 \%{ }^{3}$. However, this response is blocked by the vasodilation caused by anesthetics, which can also decrease the cardiac output. Cerebral perfusion pressure (CPP) decreases approximately $15 \%$ in the non-anesthetized patient in the sitting position ${ }^{2}$ and it can decrease even more during anesthesia due to vasodilation and reduction in venous return.

The observations of Enderby ${ }^{4}$ that there is a reduction of 0.8 $\mathrm{mmHg}$ in systolic blood pressure (SBP) for each $1 \mathrm{~cm}$ elevation in relation to the heart are classic. Since MAP is directly proportional to SBP, it is obvious that elevation of the head in relation to the heart leads to a reduction of MAP in the intracranial territory, which is accentuated during anesthesia due to the reasons mentioned before.

Cerebral perfusion pressure depends directly on the MAP according to the equation:

$$
\mathrm{CPP}=\mathrm{MAP}-\mathrm{CVP}^{*}
$$

The concept that self-regulatory mechanisms of the cerebral blood flow (CBF) tend to maintain a constant flow when MAP is between 50 and $150 \mathrm{mmHg}$ is also classic ${ }^{5}$. When MAP is below $50 \mathrm{mmHg}$, self-regulatory mechanisms do not work and $\mathrm{CBF}$ shows a linear and dangerous reduction paralleling the CPP.

In view of those considerations, maintenance of MAP equal or above $50 \mathrm{mmHg}$ has been recognized as the safety threshold in hypotensive anesthesia, which is used to reduce perioperative bleeding ${ }^{6}$.

Here, two important considerations should be made.

First, in the sitting position MAP in the brain is smaller than the MAP measured at the upper extremity when the patient is supine due to the observations of Enderby mentioned be-

${ }^{*} \mathrm{CVP}=$ Central Venous Pressure; normal $\cong 8 \mathrm{mmHg}$ fore ${ }^{4}$. This difference is frequently ignored by the anesthesiologist and can endanger adequate cerebral perfusion during the procedure in the sitting position.

Second, the inferior limit of MAP of $50 \mathrm{mmHg}$ for the mechanism of self-regulation of the CBF has been questioned by some authors ${ }^{7,8}$, who prefer to work with a mean value of $80 \mathrm{mmHg}$, below which the mechanism would not function properly and CBF would fall especially in patients with poorly controlled hypertension.

In the case discussed here, arterial pressure was monitored by a non-invasive method in the arm, and evidence indicates that the pressure gradient between the arm and the brain was ignored. It is considered that in a patient in the beach chair position there is a $30-\mathrm{cm}$ height difference between the base of the brain (more elevated) and the heart. A blood pressure of $80 \times 45 \mathrm{mmHg}$ in the arm corresponds to a MAP of $56 \mathrm{mmHg}$. However, the difference in systolic pressure between the heart and the base of the brain, which is more elevated, is approximately $24 \mathrm{mmHg}$, meaning that the SBP at the base of the brain is around $56 \mathrm{mmHg}$ and MAP is about $48 \mathrm{mmHg}$, which does not take into consideration the probable change in diastolic blood pressure. At the cephalad portion of the cerebral cortex, more elevated than the base of the brain, one should add another $10 \mathrm{~cm}$ in relation to the level of the heart bringing the SBP to $48 \mathrm{mmHg}$ and MAP to $43 \mathrm{mmHg}$.

The analysis of those values is consistent with the outcome of this patient. Axial CT of the head on the $5^{\text {th }}$ postoperative day showed cerebral edema and cisternal occlusion; MRI indicated cortical infarctions in both cerebral hemispheres without evidence of intracranial bleeding. Therefore, the lesions were compatible with intraoperative cerebral hypoperfusion. Besides, the patient was anesthetized with isoflurane, which is known to have vasodilator properties and it certainly hindered a probable increase in systemic vascular resistance to compensate a reduction in MAP and in other circulatory parameters caused by the sitting position.

The lessons of a catastrophic event, such as the one described here, should be taken into consideration in other situations in which the surgery is performed with elevation of the head and the surgeon requests hypotensive anesthetic technique to reduce intraoperative bleeding.

Plastic surgery of the breasts in the sitting position with epidural anesthesia and sedation is one of them. In this case, a reduction in MAP in the brain caused by the elevation of the head will not be compensated by an increase in systemic vascular resistance, since the epidural block (similar to the isoflurane in the case described here) tends to cause vasodilation and reduction in systemic vascular resistance. Under sedation, it is difficult for the anesthesiologist to detect signs of cerebral hypoperfusion during the procedure, and the catastrophe only becomes apparent postoperatively.

The knowledge of physiological changes related with the sitting position, as well as the effects of gravity on blood pressure (and consequently in perfusion) in the brain is fun- 
damental for the prevention of severe neurological complications in surgeries with the patient in this position, regardless of the anesthetic technique used.

Key Words: ANESTHESIA, General; COMPLICATIONS: neurological lesion; positioning

José Roberto Nociti, TSA

Member of the Editorial Council of the Brazilian Journal of Anesthesiology; Vice-President of the World Federation of Societies of Anesthesiologists; Responsible for the CET-SBA Santa Casa de Misericórdia de Riberão Preto, SP

\section{REFERÊNCIAS - REFERENCES}

01. Cullen DJ, Kirby RR - Beach chair position may decrease cerebral perfusion. APSF Newsletter 2007;22:25-27.

02. Warner MA, Martin JT - Patient Positioning, em: Barash PG, Cullen BF, Stoelting RK - Clinical Anesthesia, $4^{\text {th }}$ Ed, Philadelphia, Lippincott Williams \& Wilkins, 2001;639-665.

03. Gauer $\mathrm{OH}$, Thron $\mathrm{HL}$ - Postural Changes in the Circulation, em: Hamilton WF, Dow P - Handbook of Physiology. Washington DC, American Physiological Society, 1965; v.3, sect. 2:2409.

04. Enderby GEH - Postural ischaemia and blood pressure. Lancet, 1954;1:185.

05. Michenfelder JD - Anesthesia and the Brain. New York, Churchill Livingstone, 1988;94-113.

06. Thompson GE, Miller RD, Stevens WC - Hypotensive anesthesia for total hip arthroplasty: a study of blood loss and organ function (brain, heart, liver, and kidney). Anesthesiology, 1978; 48:91-96.

07. Drummond JC - The lower limit of autoregulation: time to revise our thinking? Anesthesiology, 1997;86:1431-1433.

08. Drummond JC, Patel PM - Neurosurgical Anesthesia, em: Miller $\mathrm{RD}-$ Anesthesia, $5^{\text {th }} \mathrm{Ed}$, Philadelphia, Churchill Livingstone, 2000;1895-1933. 